\section{JURNAL EKONOMI EFEKTIF}

ISSN : $2622-8882$, E-ISSN : 2622-9935

Jurnal Ekonomi Efektif, Vol. 3, No. 4, Juli 2021

@ Prodi Manajemen Fakultas Ekonomi Universitas

Pamulang

\title{
PENGARUH MOTIVASI DAN DISIPLIN KERJA TERHADAP KINERJA KARYAWAN PT. MEGA FINANCE KANTOR PUSAT JAKARTA SELATAN
}

\author{
Priehadi Dhasa Eka \\ Universitas Pamulang, Tangerang Selatan, Banten, Indonesia \\ dosen01577@unpam.ac.id
}

Manuskrip: Mei -2021 Ditinjau: Juni -2021; Diterima: Juni-2021; Online: Juli-2021; Diterbitkan: Juli-2021

\begin{abstract}
ABSTRAK
Penelitian ini bertujuan untuk mengetahui bagaimana pengaruh motivasi dan disiplin kerja terhadap kinerja karyawan PT. Mega Finance Kantor Pusat Jakarta Selatan. Metode yang digunakan dalam metode ini adalah pendekatan kuantitatif, pengambilan sampel menggunakan teknik slovin dengan error level sebesar 0,10 dengan begitu didapat 68 responden, Hasil penelitian secara parsial menunjukkan bahwa motivasi berpengaruh positif dan signifikan terhadap kinerja karyawan PT. Mega Finance Kantor Pusat Jakarta Selatan dengan nilai thitung $>$ ttabel atau $(2,625>1,997)$ dan disiplin kerja juga berpengaruh positif dan signifikan terhadap kinerja karyawan PT. Mega Finance Kantor Pusat Jakarta Selatan dengan nilai thitung $>$ ttabel atau $(12,483>1,997)$. Motivasi dan disiplin kerja secara simultan berpengaruh signifikan terhadap kinerja karyawan PT. Mega Finance Kantor Pusat Jakarta Selatan dengan nilai Fhitung > Ftabel atau $(84,769>3,14)$.
\end{abstract}

\section{Kata Kunci: Motivasi, Disiplin Kerja, Kinerja Karyawan}

\begin{abstract}
This study aims to determine how the influence of motivation and work discipline on the performance of employees of PT. Mega Finance South Jakarta Head Office. The method used in this method is a quantitative approach, sampling using the Slovin technique with an error level of 0.10 so obtained 68. The partial results showed that motivation had a positive and significant effect on the performance of employees of PT. Mega Finance South Jakarta Head Office with a value of tcount > ttable or $(2,625>1,997)$ and work discipline also has a positive and significant effect on the performance of employees of PT. Mega Finance South Jakarta Head Office with a value of tcount > ttable or (12,483 > 1,997). Motivation and work discipline simultaneously have a significant effect on the performance of employees of PT. Mega Finance South Jakarta Head Office with a value of Fcount > Ftable or (84,769 > 3.14).
\end{abstract}

Keywords: Motivation, Work Discipline, Employee Performance 


\section{PENDAHULUAN}

\section{A. Latar Belakang}

Sumber daya manusia merupakan penggerak utama jalannya kegiatan sebuah organisasi. Begitu juga dalam konteks organisasi bisnis atau perusahaan, maju mundurnya perusahaan ditentukan oleh keberadaan sumber daya manusianya. Manusia selalu berperan aktif dan dominan dalam setiap kegiatan organisasi karena manusia menjadi perencana, pelaku, dan penentu terwujudnya tujuan organisasi, oleh karena itu keberhasilan suatu perusahaan tidak hanya tergantung dengan teknologi perusahaan melainkan juga tergantung pada aspek sumber daya manusia yang dimiliki oleh perusahaan. Sehingga suatu perusahaan membutuhkan sumber daya manusia yang potensial, baik pemimpin maupun karyawan dapat memberikan kontribusi yang baik dan melaksanakan tugas dengan optimal untuk mencapai tujuan perusahaan. Karena semua kegiatan perusahaan akan melibatkan tindakan sumber daya manusia yang ada didalamnya. Sumber daya manusia atau karyawan dalam sebuah perusahaan menjadi perhatian penting dalam rangka usaha mencapai keberhasilan perusahaan. Keberhasilan suatu perusahaan sangat dipengaruhi oleh kinerja individu karyawannya. Setiap perusahaan akan selalu berusaha untuk mendapatkan kinerja terbaik dari karyawannya, dengan harapan apa yang menjadi tujuan perusahaan akan tercapai dengan kinerja yang baik maka pengeluaran beban karyawan per unit akan semakin kecil.

Kinerja pada dasarnya merupakan tanggung jawab setiap individu yang bekerja dalam organisasi. Tanggung jawab terhadap kinerja sebenarnya bukan lahir dari manajer namun dari individu. Apabila dalam organisasi setiap individu bekerja dengan baik, berprestasi, bersemangat dan memberikan kontribusi terbaik mereka terhadap organisasi, maka kinerja organisasi secara keseluruhan baik. Dengan demikian, kinerja organisasi merupakan cermin dari kinerja individu (Mahmudi, 2013). Kinerja merupakan hal yang penting bagi organisasi atau perusahaan serta dari pihak pegawai itu sendiri. Oleh karena itu, kinerja pegawai akan berjalan dengan efektif apabila didukung dengan motivasi dan disiplin kerja.

Pemberian motivasi sangat penting dalam setiap perusahaan. Karyawan yang mempunyai motivasi kerja yang tinggi akan dapat mendorong karyawan tersebut bekerja lebih semangat serta dapat memberikan kontribusi positif terhadap pekerjaan yang telah menjadi tanggung jawabnya. Motivasi sebagai kekuatan yang muncul dari dalam ataupun dari luar diri seseorang dan membangkitkan semangat serta ketekunan untuk mencapai sesuatu yang diinginkan (Daft, 2010:273). Tanpa motivasi, seorang karyawan tidak dapat memenuhi pekerjaannya sesuai standar atau melampui standar karena apa yang menjadi motivasi dalam bekerja tidak terpenuhi. Sekalipun seorang karyawan yang memiliki kemampuan dalam bekerja tinggi tetapi tidak memiliki motivasi untuk menyelesaikan tugasnya maka hasil akhir dalam pekerjaannya tidak akan memuaskan.

Salah satu contoh perusahaan yang mengedepankan kualitas sumber daya manusia dengan baik adalah PT Mega Finance. PT Mega Finance merupakan perusahaan yang bernaung di bawah CT Corpora seperti halnya dengan Bank Mega, Trans TV, Trans7, Baskin robins, Transmart Carrefour dan lain-lain. CT Corpora merupakan adalah perusahaan holding yang berbasis di Indonesia memegang perusahaan yang aktif di beberapa industri. Kelompok perusahaan ini dibagi menjadi tiga bisnis utama, yaitu dalam bidang keuangan \& pembiayaan, media, gaya hidup \& hiburan serta sumber daya alam. Kantor pusat PT Mega Finance berlokasi di Graha Mega Finance, Jalan Wijaya I No. 19 Kelurahan Petogogan Kecamatan Kebayoran Baru, Jakarta Selatan. Awal berdiri 
pada tanggal 15 Maret 1995, dengan nama Para Finance. Pada Juni 2010, Chairul Tanjung (Chairman) mengeluarkan kebijakan untuk mengganti nama Para Finance menjadi Mega Finance. Mega Finance bergerak di bidang leasing (sewa guna usaha), factoring (anjak piutang), dan pembiayaan konsumen. Mega Finance awalnya berfokus pada pembiayaan kendaraan roda dua seperti Honda, Yamaha, Suzuki, Kawasaki dan Vespa. Bisnis Mega Finance pun semakin berkembang dengan hadirnya pembiayaan elektronik (Mega Zip) dan pembiayaan multiguna. Mega Zip hadir di kota-kota besar, khususnya di Transmart Carrefour, Hypermart, Electronic Solution dan modern store lainnya bahkan saat ini Mega Zip hadir di toko-toko tradisional dipelosok wilayah pun, sehingga semakin dekat dengan konsumen di seluruh Indonesia. Sedangkan pembiayaan multiguna hadir untuk membantu konsumen yang membutuhkan biaya untuk pengobatan, pendidikan, dan kebutuhan lain-lain dengan proses yang cepat. Saat ini PT. Mega Finance memiliki kurang lebih 100 cabang yang tersebar diseluruh wilayah nusantara dan bekerjasama dengan 3000 toko dengan total karyawan sebanyak 879 karyawan dengan karyawan kantor pusat sebanyak 211 orang termasuk penulis sendiri.

PT Mega Finance memiliki misi salah satunya adalah menyediakan tempat berkarya dan pengembangan diri bagi karyawan yang memiliki dedikasi, motivasi, dan kualitas tinggi. Pada PT. Mega Finance dalam meningkatkan motivasi karyawan yaitu dengan memberikan apresiasi kepada karyawan apabila berhasil memenuhi tugas maupun target perusahaan dengan baik. Motivasi sangat penting dalam meningkat kinerja, PT. Mega Finance sendiri dalam meningkat motivasi karyawan adalah dengan cara mengadakan coffee morning, family gathering, pelatihan yang berisi materi pengembangan diri. namun hal tersebut dirasa kurang optimal karena antara target dan pencapaian kiranya belum tercapai dengan maksimal.

Tabel 1. Hasil Pra Survey Mengenai Motivasi Kerja

\begin{tabular}{|c|l|c|c|c|c|c|}
\hline \multirow{2}{*}{ No } & \multirow{2}{*}{ Indikator } & \multicolumn{5}{c|}{ Tahun } \\
\cline { 3 - 7 } & & $\mathbf{2 0 1 6}$ & $\mathbf{2 0 1 7}$ & $\mathbf{2 0 1 8}$ & $\mathbf{2 0 1 9}$ & $\mathbf{2 0 2 0}$ \\
\hline 1. & Dimensi Ketentraman: & & & & & \\
\hline & Pemberian Bonus Karyawan & Tidak Ada & Ada & Ada & Ada & Tidak Ada \\
\hline & Tunjangan Kesehatan BPJS & Ada & Ada & Ada & Ada & Ada \\
\hline & Ruang Bermain dan Bersantai & Tidak Ada & Tidak Ada & Tidak Ada & Tidak Ada & Ada \\
\hline 2. & Dimensi Dorongan: & & & & & \\
\hline & Reward Karyawan Teladan & Tidak Ada & Tidak Ada & Tidak Ada & Ada & Tidak Ada \\
\hline & Promosi Jabatan & Ada & Ada & Ada & Ada & Tidak Ada \\
\hline
\end{tabular}

Sumber: Data PT. Mega Finance Kantor Pusat 2021

Berdasarkan dari tabel diatas dapat dilihat bahwa sebagian besar indikator Motivasi telah dilaksanakan oleh PT Mega Finance Kantor Pusat seperti salah satunya adalah program reward yang dijalankan oleh PT Mega Finance saat ini adalah "Mega Star" program tersebut diadakan diseluruh cabang dan kantor pusat, Dengan diadakan program tersebut memungkinkan karyawan terdorong berfikiran untuk menjadi pemenang dalam program Mega Star maka seluruh karyawan cabang dan kantor pusat untuk selalu hadir ke kantor dan datang dengan tepat waktu. Tidak hanya reward saja yang digunakan perusahaan dalam meningkatkan motivasi yaitu dengan kenaikan gaji, tunjangan dan promosi kerja yang tetap dipertimbangkan dengan kemampuan yang dimiliki oleh karyawan.

Selain motivasi yang berpengaruh terhadap kinerja karyawan adalah disiplin kerja, suatu perusahaan dituntut memiliki pandangan dan sikap disiplin untuk meningkatkan kinerja karyawan. Disiplin kerja merupakan salah satu komponen yang turut menentukan 
baik buruknya kinerja seseorang, karyawan yang disiplin dalam bekerja akan cenderung untuk melakukan segala aktivitas perusahaan dengan tata aturan standar maupun tugas dan tanggung jawab yang menjadi kewajibannya. Contoh sederhana dalam hal ini ialah jika seseorang karyawan sering datang terlambat maka secara otomatis hal tersebut akan merugikan perusahaan tempat ia bekerja salah satu contoh kerugian yang dapat dilihat adalah berkurangnya jam kerja bagi karyawan yang bersangkutan sehingga kemungkinan target kerja yang molor atau tidak sesuai dengan jadwal yang sudah ditetapkan akan sangat besar serta munculnya sikap malas dan acuh tak acuh pada diri karyawan. Disiplin yang baik mencerminkan besarnya tanggung jawab seseorang terhadap tugas yang telah diberikan kepadanya, hal ini mendorong gairah kerja, semangat kerja dan terwujudnya tujuan perusahaan. Dibawah ini adalah data kedisiplinan PT Mega Finance Kantor Pusat Jakarta:

Tabel 2. Rekap Surat Peringatan Karyawan PT Mega Finance Kantor Pusat

\begin{tabular}{|c|c|c|c|c|c|}
\hline \multirow{2}{*}{ No } & \multirow{2}{*}{ Tahun } & \multicolumn{4}{|c|}{ Jumlah Surat Peringatan } \\
\cline { 3 - 6 } & & SP1 & SP2 & SP3 & $\begin{array}{c}\text { Total } \\
\text { Pertahun }\end{array}$ \\
\hline 1. & 2016 & 13 & 4 & 1 & 18 \\
\hline 2. & 2017 & 18 & 7 & 3 & 28 \\
\hline 3. & 2018 & 29 & 19 & 8 & 56 \\
\hline 4. & 2019 & 37 & 15 & 9 & 61 \\
\hline 5. & 2020 & 43 & 25 & 11 & 79 \\
\hline \multicolumn{2}{|c|}{ Total } & 140 & 70 & 32 & \\
\hline
\end{tabular}

Sumber: Data PT. Mega Finance Kantor Pusat 2021

Dapat dilihat pada tabel menerangkan bahwa data surat peringatan meningkat yang artinya jumlah pelanggaran karyawan dari tahun 2016-2020 mengalami kenaikan dalam setiap tahunnya, tingkar disiplinan pada karyawan PT Mega Finance pun menurun.

Tabel 3. Penilaian Kinerja Karyawan PT Mega Finance tahun 2019

\begin{tabular}{|c|c|c|c|c|c|c|c|c|c|c|}
\hline \multirow{2}{*}{ No } & \multirow{2}{*}{$\begin{array}{c}\text { Penilaian Kinerja } \\
\text { Karyawan }\end{array}$} & \multicolumn{9}{|c|}{ Nilai Yang Dicapai } \\
\hline & & Target & 2017 & $\%$ & Target & 2018 & $\%$ & Target & 2019 & $\%$ \\
\hline 1. & Kualitas & 125 & 120 & $96 \%$ & 150 & 128 & $85 \%$ & 175 & 131 & $75 \%$ \\
\hline 2. & Kuantitas & 100 & 98 & $98 \%$ & 175 & 158 & $90 \%$ & 200 & 183 & $92 \%$ \\
\hline 3. & Tanggung Jawab & 100 & 95 & $95 \%$ & 175 & 151 & $86 \%$ & 200 & 172 & $86 \%$ \\
\hline 4. & Pelaksanakan Tugas & 125 & 118 & $94 \%$ & 150 & 132 & $88 \%$ & 175 & 146 & $83 \%$ \\
\hline 5 & Penekanan Biaya & 125 & 89 & $71 \%$ & 175 & 142 & $81 \%$ & 200 & 158 & $79 \%$ \\
\hline 6 & Pengawasan & 100 & 89 & $89 \%$ & 150 & 127 & $85 \%$ & 175 & 137 & $78 \%$ \\
\hline & Total & & & $90 \%$ & & & $86 \%$ & & & $82 \%$ \\
\hline
\end{tabular}

Sumber: Data PT Mega Finance Kantor Pusat (2020)

Dapat dilihat dari tabel penilaian kinerja diatas bahwa rata-rata indikator diatas mengalami penurunan disetiap tahunnya. Masih ada beberapa hal yang perlu di tingkatkan diantaranya mengenai kinerja karyawan. Tetapi berdasarkan observasi peneliti menurunnya performance karyawan bisa jadi disebabkan karena ada nya faktor dari Motivasi dan Disiplin Kerja, Berdasarkan uraian latar belakang di atas maka penulis tertarik untuk meneliti lebih lanjut terhadap variabel-variabel di atas. Untuk itu saya menyelesaikan penelitian dengan judul "Pengaruh Motivasi dan Disiplin Kerja terhadap Kinerja Karyawan PT. Mega Finance Kantor Pusat Jakarta Selatan.” 


\section{B. Rumusan Masalah}

1. Apakah terdapat pengaruh motivasi pada kinerja karyawan PT. Mega Finance Kantor Pusat?

2. Apakah terdapat pengaruh disiplin kerja karyawan pada kinerja karyawan PT. Mega Finance Kantor Pusat?

3. Apakah terdapat pengaruh motivasi dan disiplin kerja terhadap kinerja karyawan PT. Mega Finance Kantor Pusat?

\section{Tujuan Penelitian}

1. Untuk mengetahui pengaruh motivasi terhadap kinerja karyawan PT. Mega Finance Kantor Pusat.

2. Untuk mengetahui pengaruh disiplin kerja terhadap kinerja karyawan PT. Mega Finance Kantor Pusat.

3. Untuk mengetahui pengaruh motivasi dan disiplin kerja terhadap kinerja karyawan PT. Mega Finance Kantor Pusat.

\section{TINJAUAN PUSTAKA}

\section{Motivasi}

Secara umum definisi atau pengertian motivasi dapat diartikan sebagai suatu tujuan atau pendorong, dengan tujuan sebenarnya tersebut yang menjadi daya penggerak utama bagi seseorang dalam berupaya dalam mendapatkan atau mencapai apa yang diinginkannya baik itu secara positif ataupun negatif. Menurut Hasibuan (2016:146) motivasi adalah pemberian daya penggerak yang menciptakan kegairahan kerja seseorang agar mereka mau bekerja sama, bekerja efektif, dan terintegrasi dengan segala daya upayanya untuk mencapai kepuasan.

Menurut Indah Puji Hartatik (2014:160) mendefinisikan motivasi adalah cara mengerahkan daya dan potensi bawahan agar mau bekerja sama secara produktif dalam mencapai dan mewujudkan tujuan yang ditetapkan. Menurut Mangkunegara (2017:76) mengemukakan motivasi merupakan kondisi atau energi yang menggerakkan diri karyawan yang terarah atau tertuju untuk mencapai tujuan organisasi perusahaan. Menurut Robins dalam Donni Juni Priansa (2016) menyatakan bahwa motivasi adalah proses yang menunjukan intensitas individu, arah dan ketekunan dari upaya menuju pencapaian tujuan.

Serta menurut Steers \& Porter dalam Miftahun \& Sugiyanto (2010) menyatakan bahwa motivasi kerja adalah suatu usaha yang dapat menimbulkan suatu perilaku, mengarahkan perilaku, dan memelihara atau mempertahankan perilaku yang sesuai dengan lingkungan kerja dalam organisasi. Karyawan yang mempunyai motivasi kerja tinggi akan berusaha agar pekerjaannya dapat terselesaikan dengan sebaik-baiknya.

Berdasarkan uraian diatas yang membahas mengenai definisi motivasi, penulis dapat menyimpulkan motivasi merupakan kondisi atau energi untuk menggerakkan diri kearah atau tertuju untuk mencapai tujuan yang ditetapkan.

\section{Disiplin Kerja}

Menurut Hasibuan (2018:193) kedisplinan adalah fungsi operatif keenam dari manajemen sumber daya manusia. Kedisiplinan merupakan fungsi operatif MSDM yang terpenting karena semakin baik disiplin karyawan, semakin tinggi prestasi kerja yang dapat dicapainya. Tanpa disiplin karyawan yang baik, sulit bagi organisasi perusahaan mencapai hasil yang optimal. Menurut Henry Simamora (2014:610) mendefinisikan disiplin kerja adalah prosedur yang mengoreksi atau menghukum bawahan karena 
melanggar peraturan atau prosedur. Disiplin merupakan bentuk pengendalian diri karyawan dan pelaksanaan yang teratur dan menunjukan tingkat kesungguhan tim kerja didalam suatu organisasi.

Menurut Indah Puji Hartatik (2014:184) Disiplin merupakan suatu alat atau sarana bagi organisasi untuk mempertahankan eksistensinya. Dengan disiplin yang tinggi, para pegawai akan menaati semua peraturan yang ada, sehingga pelaksanaan pekerjaan dapat sesuai dengan rencana yang telah ditentukan.

Menurut Singodimedjo dalam Edy Sutrisno (2016:86), menyatakan bahwa Disiplin adalah sikap kesediaan dan kerelaan seseorang untuk mematuhi dan menaati normanorma peraturan yang berlaku disekitarnya. Selain itu juga menurut Edy Sutrisno (2016:89) disiplin adalah prilaku seseorang yang sesuai dengan peraturan, prosedur kerja yang ada atau disiplin adalah sikap, tingkah laku, dan perbuatan yang sesuai dengan peraturan dari organisasi baik tertulis maupun tidak tertulis.

Menurut Priyono (2016) "Disiplin yang baik adalah disiplin diri. Banyak orang menyadari bahwa ada kemungkinan bahwa dibalik disiplin diri adalah peningkatan kemalasan. Dengan kesadaran dalam menerapkan aturan perusahaan atau badan yang tercermin dalam karya disiplin maka tinggi karyawan juga meningkat."

Berdasarkan uraian diatas yang membahas mengenai definisi disiplin kerja, penulis dapat menyimpulkan disiplin kerja merupakan sikap atau tingkah laku, dan perbuatan yang sesuai dengan peraturan baik tertulis maupun tidak tertulis. Dengan disiplin yang tinggi, para pegawai akan menaati semua peraturan yang ada, sehingga pelaksanaan pekerjaan dapat sesuai dengan rencana yang telah ditentukan.

\section{Kinerja Karyawan}

Setiap perusahaan mengharapkan setiap karyawannya menunjukkan kinerja yang optimal dalam menunjang tercapainya tujuan yang telah ditetapkan sebelumnya. Tanpa didukung oleh kinerja yang baik tentunya sebuah organisasi tidak akan maju dan berkembang. Oleh karena itu masalah yang berkaitan dengan kinerja harus mendapat perhatian pihak manajemen bila hendak mencapai tujuan yang diharapkan. Menurut Mangkunegara (2016:67) istilah kinerja berasal dari kata job performance atau Actual Permormanse (prestasi kerja atau prestasi sesungguhnya yang dicapai seseorang). pengertian kinerja adalah hasil kerja secara kualitas dan kuantitas yang dicapai oleh seorang pegawai dalam melaksanakan tugasnya sesuai dengan tanggung jawab yang diberikan kepadanya.

Menurut (Edison, 2016:190) kinerja adalah hasil dari suatu proses yang mengacu dan diukur selama periode waktu tertentu berdasarkan ketentuan atau kesepakatan yang telah ditetapkan sebelumnya. Kasmir (2016:182) mengatakan kinerja merupakan hasil kerja dan perilaku kerja yang telah dicapai dalam menyelesaikan tugas-tugas dan tanggung jawab yang diberikan dalam suatu periode tertentu. Meningkatnya kinerja perorangan (individual performance) maka kemungkinan besar juga akan meningkatkan kinerja perusahaan (coorporate performance) karena keduanya mempunyai hubungan yang erat.

Menurut Wibowo (2017:3) kinerja adalah merupakan implementasi dari rencana yang telah disusun tersebut. Implementasi kinerja dilakukan oleh sumber daya manusia yang memiliki kemampuan, kompetensi, motivasi, dan kepentingan sedangkan menurut Donni Juni Priansa (2018:29) menyatakan bahwa kinerja adalah prilaku yang nyata yang ditampikan setiap orang sebagai prestasi kerja yang dihasilkan oleh pegawai sesuai dengan perannya dalam organisasi. 
Berdasarkan uraian diatas yang membahas mengenai definisi disiplin kerja, penulis dapat menyimpulkan hasil kerja dan perilaku kerja yang telah dicapai serta mengacu dan diukur selama periode waktu tertentu sesuai dengan kesepakatan sebelumnya.

\section{METODE PENELITIAN}

\section{Populasi}

Populasi dalam penelitian ini adalah karyawan PT Mega Finance kantor pusat yang berjumlah 211 karyawan.

2. Sampel

Sampel dalam penelitian ini berjumlah 68 responden

\section{Jenis Penelitian}

Jenis penelitian yang dipakai adalah kuantitatif, dimana tujuannya adalah untuk mengetahui pengaruh antara variabel bebas terhadap variabel terikat baik parsial maupun simultan

\section{Metode Analisis Data}

Dalam menganalisis data digunakan uji instrumen, uji asumsi klasik, regresi, koefisien korelasi, koefisien determinasi dan uji hipotesis.

\section{HASIL PENELITIAN}

\section{Uji Verifikatif}

Analisis verifikatif dimaksudkan untuk mengetahui besaran pengaruh variabel independen terhadap variabel dependen dan menganalisis signifikansi dari pengaruh tersebut.

\section{a. Analisis Regresi Linier Sederhana}

Analisis Regresi Linier Sederhana adalah hubungan secara linier antara satu variabel independen $(\mathrm{X})$ dan variabel dependen $(\mathrm{Y})$. Analisis ini menunjukkan pengaruh variabel independen terhadap variabel dependen dengan persamaan sebagai berikut $\mathrm{Y}=\mathrm{a}+\mathrm{bx}$. Adapun hasil analisis regresi linier berganda yang dihitung menggunakan software system SPSS versi 26 sebagai berikut:

Tabel 4. Regresi Sederhana Variabel Motivasi Terhadap Variabel Kinerja

Karyawan

Coefficients $^{\mathrm{a}}$

\begin{tabular}{|c|c|c|c|c|c|c|}
\hline \multirow{2}{*}{\multicolumn{2}{|c|}{ Model }} & \multicolumn{2}{|c|}{$\begin{array}{c}\text { Unstandardized } \\
\text { Coefficients }\end{array}$} & \multirow{2}{*}{$\begin{array}{c}\text { Standardized } \\
\text { Coefficients } \\
\text { Beta } \\
\end{array}$} & \multirow[b]{2}{*}{$\mathrm{T}$} & \multirow[b]{2}{*}{ Sig. } \\
\hline & & $\mathrm{B}$ & Std. Error & & & \\
\hline & (Constant) & 34.081 & 4.337 & & 7.858 & .000 \\
\hline & MOTIVASI & .222 & .110 & .242 & 2.024 & .047 \\
\hline
\end{tabular}

a. Dependent Variable: KINERJA

Sumber : Data diolah, 2021

Persamaan $\mathrm{Y}=34,081+0,222 \mathrm{X}_{1}$ menunjukkan adanya pengaruh positif motivasi terhadap kinerja karyawan.

Tabel 5. Regresi Sederhana Variabel Disiplin Kerja Terhadap Variabel Kinerja

Karyawan

Coefficients $^{\mathrm{a}}$

\begin{tabular}{|c|c|c|c|c|c|}
\hline \multirow[b]{2}{*}{ Model } & \multicolumn{2}{|c|}{$\begin{array}{c}\text { Unstandardized } \\
\text { Coefficients }\end{array}$} & \multirow{2}{*}{$\begin{array}{c}\begin{array}{c}\text { Standardized } \\
\text { Coefficients }\end{array} \\
\text { Beta }\end{array}$} & \multirow[b]{2}{*}{$\mathrm{T}$} & \multirow[b]{2}{*}{ Sig. } \\
\hline & $\mathrm{B}$ & Std. Error & & & \\
\hline 1 (Constant) & 10.855 & 2.637 & & 4.117 & .000 \\
\hline DISIPLIN_KERJA & .756 & .062 & .833 & 12.220 & .000 \\
\hline
\end{tabular}

a. Dependent Variable: KINERJA 
Persamaan $\mathrm{Y}=10,855+0,756 \mathrm{X}_{2}$ menunjukkan adanya pengaruh positif motivasi terhadap kinerja karyawan.

\section{b. Analisis Regresi Linier Berganda}

Uji regresi linier berganda ini dimaksudkan untuk mengetahui besaran pengaruh variabel motivasi (X1) dan disiplin kerja (X2) terhadap kinerja karyawan (Y). Adapun hasil analisis regresi linier berganda yang dihitung menggunakan software system SPSS versi 26 sebagai berikut:

Tabel 6. Regresi Berganda

Coefficients $^{\mathrm{a}}$

\begin{tabular}{|c|c|c|c|c|c|}
\hline \multirow[b]{2}{*}{ Model } & \multicolumn{2}{|c|}{ Unstandardized Coefficients } & $\begin{array}{c}\text { Standardized } \\
\text { Coefficients }\end{array}$ & \multirow[b]{2}{*}{$\mathrm{t}$} & \multirow[b]{2}{*}{ Sig. } \\
\hline & $\mathrm{B}$ & Std. Error & Beta & & \\
\hline 6. $\quad$ (Constant & 5.238 & 3.311 & & 1.582 & .118 \\
\hline MOTIVASI & .158 & .060 & .172 & 2.625 & .011 \\
\hline DISIPLIN_KERJA & .742 & .059 & .818 & 12.483 & .000 \\
\hline
\end{tabular}

a. Dependent Variable: KINERJA

Sumber : Data diolah, 2021

Berdasarkan hasil analisis regresi pada tabel diatas, diperoleh persamaan regresinya adalah $\mathrm{Y}=5,328+0,158 \mathrm{X} 1+0,742 \mathrm{X} 2$

Intepretasi dari persamaan diatas adalah bahwa koefisien regresi variabel motivasi (X1) 0,158 dan disiplin kerja (X2) 0,742, yaitumengandung implikasi bahwa motivasi dan disiplin kerja berpengaruh positif dan searah dengan variabel kinerja karyawan.

\section{c. Analisis Koefisien Korelasi}

Analisis koefisien korelasi dimaksudkan untuk mengetahui tingkat kekuatan pengaruh atau hubungan antara variabel independen terhadap variabel dependen baik secara parsial maupun simultan. Adapun hasil analisisnya yang dihitung menggunakan software system SPSS versi 26 sebagai berikut :

Tabel 7. Hasil Uji Analisis Koefisien Korelasi

\section{Correlations}

\begin{tabular}{|ll|r|r|r|}
\hline & & MOTIVASI & $\begin{array}{c}\text { DISIPLIN } \\
\text { KERJA }\end{array}$ & KINERJA \\
\hline MOTIVASI & Pearson Correlation & 1 & .085 & $.242^{*}$ \\
& Sig. (2-tailed) & & .489 & .047 \\
& $\mathrm{~N}$ & 68 & 68 & 68 \\
\hline DISIPLIN_KERJA & Pearson Correlation & .085 & 1 & $.833^{* *}$ \\
& Sig. (2-tailed) & .489 & & .000 \\
& $\mathrm{~N}$ & 68 & 68 & 68 \\
\hline KINERJA & Pearson Correlation & $.242^{*}$ & $.833^{* *}$ & 1 \\
& Sig. (2-tailed) & .047 & .000 & \\
& $\mathrm{~N}$ & 68 & 68 & 68 \\
\hline
\end{tabular}

*. Correlation is significant at the 0.05 level (2-tailed).

**. Correlation is significant at the 0.01 level (2-tailed).

Sumber : Data diolah, 2021

Dari tabel diatas dapat dilihat bahwa nilai korelasi antara motivasi dengan disiplin kerja sebesar 0,085 atau 8,5\%. Sedangkan nilai korelasi disiplin terhadap kinerja karyawan sebesar 0,833 atau 83\% karena koefisien mendekati 1, maka dapat disimpulkan bahwa antara disiplin kerja dan kinerja karyawan memiliki hubungan yang kuat dan nilai korelasi motivasi dengan kinerja karyawan sebesar 
0,242 atau 24\%. Angka koefisien positif yang menunjukkan hubungan positif yaitu jika motivasi meningkat maka kinerja karyawan juga meningkat dan disiplin kerja meningkat maka kinerja karyawan juga meningkat.

\section{c. Analisis Koefisien Determinasi}

Analisis koefisien determinasi dimaksudkan untuk mengetahui persentase pengaruh variabel independen terhadap variabel dependen baik secara parsial maupun secara simultan. Dalam analisis ini digunakan rumus KD $=\mathrm{R} 2 \times 100 \%$.

Adapun hasil analisis yang dihitung menggunakan software system SPSS versi 26 sebagai berikut :

Tabel 8. Hasil Uji Analisis Koefisien Determinasi

\section{Model Summary}

\begin{tabular}{|l|r|r|r|r|}
\hline Model & $\mathrm{R}$ & $\mathrm{R}$ Square & $\begin{array}{c}\text { Adjusted R } \\
\text { Square }\end{array}$ & $\begin{array}{c}\text { Std. Error of the } \\
\text { Estimate }\end{array}$ \\
\hline 1 & $.850^{\mathrm{a}}$ & .723 & .714 & 2.887 \\
\hline
\end{tabular}

a. Predictors: (Constant), DISIPLIN_KERJA, MOTIVASI

Sumber : Data diolah, 2021

Berdasarkan perhitungan pada tabel diatas, diperoleh nilai koefisien determinasi (R-Square) sebesar 0,714, maka dapat disimpulkan bahwa motivasi (X1) dan disiplin kerja (X2) secara bersama-sama memiliki kontribusi pengaruh sebesar $71,4 \%$ terhadap kinerja karyawan (Y). Sementara untuk 28,6\% (100\% - 71,4\%) kinerja karyawan dijelaskan oleh faktor lain diluar motivasi dan disiplin kerja.

\section{Uji Signifikasi}

\section{a. Uji t}

Uji $\mathrm{t}(\mathrm{t}$ - test) merupakan uji parsial yang digunakan dalam pengujian hipotesis yang menggunakan analisis linear sederhana. Pengujian hipotesis secara parsial dimaksudkan untuk menguji secara stastistik (uji t) apakah rumusan hipotesis yang dibuat diterima atau ditolak. Pengujian pengaruh dalam penelitian ini antara variabel independen terhadap variabel dependen secara parsial dengan kriteria sebagai berikut:

1) Jika Sig $<0,05$ atau $t$ hitung $>t$ tabel maka $H_{o}$ ditolak dan $H_{a}$ diterima ada pengaruh signifikan

2) Jika Sig $>0,05$ atau thitung $<\mathrm{t}$ tabel maka $\mathrm{H}_{\mathrm{o}}$ diterima dan $\mathrm{H}_{\mathrm{a}}$ ditolak tidak ada pengaruh signifikan.

3) $\mathrm{t}$ tabel $=\mathrm{t}(\alpha / 2) ; \mathrm{n}-\mathrm{k}-1=\mathrm{t}(0,025 ; 65)=1,997$

Dengan rumusan hipotesisnya adalah :

$\mathrm{H}_{0}: \rho 1$ : Tidak terdapat pengaruh yang signifikan antara motivasi terhadap kinerja karyawan pada PT. Mega Finance Kantor Pusat secara parsial.

$\mathrm{H}_{\mathrm{a}}$ : $\rho 1$ : Terdapat pengaruh yang signifikan antara motivasi terhadap kinerja karyawan pada PT. Mega Finance Kantor Pusat secara parsial.

$\mathrm{H}_{0}: \rho 2$ : Tidak terdapat pengaruh yang signifikan antara disiplin kerja terhadap kinerja karyawan pada PT. Mega Finance Kantor Pusat secara parsial.

$\mathrm{H}_{\mathrm{a}}: \rho 2$ : Terdapat pengaruh yang signifikan antara disiplin kerja terhadap kinerja karyawan pada PT. Mega Finance Kantor Pusat secara parsial.

Adapun hasil pengujian hipotesis tersebut diatas yang dihitung menggunakan software system SPSS versi 26, sebagai berikut : 
Tabel 9. Hasil Uji t

Coefficients $^{\mathrm{a}}$

\begin{tabular}{|l|r|r|r|r|r|}
\hline \multirow{2}{*}{ Model } & \multicolumn{2}{|c|}{$\begin{array}{c}\text { Unstandardized } \\
\text { Coefficients }\end{array}$} & \multicolumn{1}{c|}{$\begin{array}{c}\text { Standardized } \\
\text { Coefficients }\end{array}$} & \\
\cline { 2 - 4 } & \multicolumn{1}{c|}{$\mathrm{B}$} & Std. Error & \multicolumn{1}{c|}{ Beta } & \multicolumn{1}{c|}{ T } & \multicolumn{1}{c|}{ Sig. } \\
\hline (Constant) & 5.238 & 3.311 & & 1.582 & .118 \\
MOTIVASI & .158 & .060 & .172 & 2.625 & .011 \\
DISIPLIN_KERJA & .742 & .059 & .818 & 12.483 & .000 \\
\hline
\end{tabular}

a. Dependent Variable: KINERJA

Sumber : Data diolah, 2021

Berdasarkan tabel dapat diketahui nilai Sig. untuk pengaruh motivasi (X1) terhadap kinerja karyawan (Y) sebesar 0,011 <0,05 atau nilai t hitung 2,625 > t tabel 1,997 sehingga dapat disimpulkan bahwa Ho: $\rho 1$ ditolak dan Ha: $\rho 1$ diterima ada pengaruh signifikan antara motivasi terhadap kinerja karyawan PT. Mega Finance secara parsial dan nilai Sig. untuk Disiplin Kerja (X2) terhadap Kinerja Karyawan $(\mathrm{Y})$ sebesar $0,000<0,05$ atau nilai thitung 12,483 $>$ t tabel 1,997 sehingga dapat disimpulkan bahwa Ho: $\rho 2$ ditolak dan Ha: $\rho 2$ diterima ada pengaruh signifikan antara disiplin kerja terhadap kinerja karyawan pada PT. Mega Finance secara parsial.

\section{b. Uji F}

Untuk mengetahui pengaruh variabel motivasi (X1) dan disiplin kerja (X2) terhadap variabel kinerja karyawan (Y) dapat dilakukan dengan uji statistik F (uji simultan) dengan kriteria sebagai berikut:

1) Jika Sig < 0,05 atau thitung $>$ F tabel, maka dapat dikatakan terdapat pengaruh yang signifikan secara bersama-sama antara variabel bebas terhadap variabel terikat.

2) Jika Sig > 0,05 atau t hitung < F table, maka tidak terdapat pengaruh yang signifikan secara bersama-sama antara variabel bebas terhadap variabel terikat.

3) $\mathrm{F}$ tabel $=\mathrm{F}(\mathrm{k} ; \mathrm{n}-\mathrm{k})=(2 ; 66)=3,14$

Dengan rumusan hipotesisnya adalah :

$\mathrm{H}_{0}: \rho_{3}$ : Tidak terdapat pengaruh yang signifikan antara motivasi dan disiplin kerja terhadap kinerja karyawan pada PT. Mega Finance Kantor Pusat secara simultan.

$\mathrm{H}_{\mathrm{a}}: \rho_{3}$ : Terdapat pengaruh yang signifikan antara motivasi dan disiplin

kerja terhadap kinerja karyawan pada PT. Mega Finance Kantor Pusat secara simultan.

Adapun hasil pengujian hipotesis tersebut diatas yang dihitung menggunakan software system SPSS versi 26, sebagai berikut:

\section{Tabel 10. Hasil Uji F}

ANOVA ${ }^{\mathrm{a}}$

\begin{tabular}{|c|c|c|c|c|c|}
\hline Model & $\begin{array}{l}\text { Sum of } \\
\text { Squares }\end{array}$ & Df & $\begin{array}{c}\text { Mean } \\
\text { Square }\end{array}$ & $\mathrm{F}$ & Sig. \\
\hline 1 Regression & 1412.636 & 2 & 706.318 & 84.769 & $.000^{\mathrm{b}}$ \\
\hline Residual & 541.599 & 65 & 8.332 & & \\
\hline Total & 1954.235 & 67 & & & \\
\hline
\end{tabular}

a. Dependent Variable: KINERJA

b. Predictors: (Constant), DISIPLIN_KERJA, MOTIVASI

Sumber : Data diolah, 2021

Berdasarkan tabel dapat diketahui nilai Sig untuk pengaruh motivasi (X1) dan disiplin kerja (X2) secara simultan terhadap kinerja karyawan (Y) adalah sebesar 
$0,000<0,05$ atau nilai $\mathrm{F}$ hitung 84,769 $>\mathrm{F}$ tabel 3,14 sehingga dapat disimpulkan bahwa $\mathrm{H}_{\mathrm{a}}: \rho_{3}$ ditolak dan $\mathrm{H}_{\mathrm{a}}: \rho_{3}$ diterima dapat disimpulkan bahwa Terdapat pengaruh yang signifikan antara motivasi dan disiplin kerja terhadap kinerja karyawan pada PT. Mega Finance secara simultan.

\section{Pembahasan Penelitian}

Penelitian ini bertujuan untuk mengetahui pengaruh motivasi dan disiplin kerja terhadap kinerja karyawan PT Mega Finance Kantor Pusat Jakarta Selatan. Setelah seluruh data dalam penelitian ini diuraikan, Pembahasan masing-masing variabel disajikan sebagai berikut:

\section{Pengaruh Motivasi Terhadap Kinerja Karyawan PT. Mega Finance Kantor Pusat Jakarta Selatan.}

Hasil uji simultan dan uji parsial dimana nilai t hitung $\mathrm{X} 1=2,625$ pada taraf kesalahan 5\% atau nilai signifikansi $0,011<0,05$ menunjukkan bahwa ada pengaruh yang signifikan motivasi terhadap kinerja karyawan diperkuat dengan uji analisis koefisien korelasi sebesar 0,242 atau $24 \%$ pada hubungan motivasi dan kinerja karyawan berada pada rentang interprestasi hubungan yang rendah. Hasil analisis dari penelitian ini menunjukkan bahwa motivasi berpengaruh terhadap kinerja karyawan PT Mega Finance Kantor pusat dalam hal pengakuan dari atasan dapat kita lihat pada hasil kuisioner indikator tersebut memiliki nilai skor tertinggi yaitu 4,04 (baik) dalam pelaksanaannya perusahaan memberikan pujian terhadap karyawan yang berprestasi sehingga karyawan memiliki rasa semangat atau dorongan dalam mencapai prestasi kerja. Maka dapat disimpulkan bahwa motivasi berpengaruh positif terhadap kinerja karyawan.

2. Pengaruh Disiplin Kerja Terhadap Kinerja Karyawan PT. Mega Finance Kantor Pusat Jakarta Selatan.

Hasil uji simultan dan uji parsial dimana nilai t hitung X2 $=12,483$ pada taraf kesalahan 5\% atau nilai signifikansi $0,000<0,05$ menunjukkan bahwa ada pengaruh yang signifikan motivasi terhadap kinerja karyawan diperkuat dengan uji analisis koefisien korelasi sebesar 0,833 atau 83\% pada hubungan motivasi dan kinerja karyawan berada pada rentang interprestasi hubungan yang sangat kuat. Hasil analisis dari penelitian ini menunjukkan bahwa disiplin kerja berpengaruh terhadap kinerja karyawan PT Mega Finance Kantor pusat dalam hal ketegasan dapat kita lihat pada hasil kuisioner indikator tersebut memiliki nilai skor tertinggi yaitu 4,65 (sangat baik). Maka dapat disimpulkan bahwa disiplin kerja berpengaruh positif terhadap kinerja karyawan.

\section{Pengaruh Motivasi Dan Disiplin Kerja Terhadap Kinerja Karyawan}

\section{PT. Mega Finance Kantor Pusat Jakarta Selatan.}

Hasil uji parsial dan uji simultan dengan nilai $F$ hitung sebesar 84,769 > 3,14 pada taraf kesalahan 5\% menunjukkan bahwa ada pengaruh yang signifikan sehingga dapat disimpulkan bahwa $\mathrm{H}_{0}: \rho_{3}$ ditolak dan $\mathrm{H}_{\mathrm{a}}: \rho_{3}$ diterima, diperkuat dengan kontribusi $\mathrm{R}$ Square sebesar 0,714 atau 71,4\% atau berada pada tingkat hubungan yang kuat. Maka dapat disimpulkan bahwa motivasi dan disiplin kerja berpengaruh positif terhadap kinerja karyawan.

\section{KESIMPULAN DAN SARAN}

1. Kesimpulan

a. Berdasarkan hasil pengujian uji $t$ untuk variabel motivasi diperoleh nilai $t_{\text {hitung }}>t_{\text {tabel }}$ atau $(2,625>1,997)$ hal ini diperkuat dengan nilai signifikansi $0,011<0,05$, yang 
menyatakan terdapat pengaruh yang positif dan signifikan secara parsial antara variabel motivasi terhadap kinerja karyawan.

b. Terdapat pengaruh yang positif dan signifikan secara parsial antara variabel disiplin kerja terhadap kinerja karyawan dengan diperoleh nilai $t_{\text {hitung }}>t_{\text {tabel }}$ atau $(12,483>$ 1,997) hal ini diperkuat dengan nilai signifikansi $0,000<0,05$. Berdasarkan hasil pembahasan pada penelitian yang sudah dilakukan oleh peneliti, dari hasil analisis regresi linier berganda diperoleh persamaan regresinya yaitu: $Y=\mathbf{5 , 3 2 8}+\mathbf{0 , 1 5 8} X 1$ + 0,742 X2. Hal tersebut dapat disimpulkan bahwa koefisien regresi variabel motivasi 0,158 dan 0,742 yaitu mengandung implikasi bahwa motivasi dan disiplin kerja berpengaruh positif dan searah dengan variabel kinerja karyawan.

c. Terdapat pengaruh yang positif dan signifikan secara simultan bersama-sama antara variabel motivasi dan disiplin kerja terhadap kinerja karyawan pada PT Mega Finance Kantor pusat Jakarta Selatan, dapat dilihat dari nilai yang diperoleh yaitu $F_{\text {hitung }}>\mathrm{F}_{\text {tabel }}$ atau $(84,769>3,14)$ hal ini diperkuat dengan nilai probability sig sebesar $0,000<0,05$.

\section{Saran}

a. Dari hasil jawaban responden, indikator kondisi kerja mendapatkan skor terendah sebesar 3,79 pada variabel motivasi namun sudah dalam kondisi yang baik. Perusahaan perlu memperhatikan keadaan atau kondisi situasi lingkungan kerja supaya kondusif dalam hal ini yaitu suasana yang nyaman dan menyenangkan agar karyawan dapat bekerja dengan tenang sehingga kinerja tidak terganggu.

b. Dari hasil jawaban responden, indikator keadilan mendapatkan skor terendah sebesar 3,44 walaupun sudah dalam kondisi yang baik pada variabel disiplin kerja. Perusahaan perlu memperhatikan keadilan karena keadilan menjadi dasar kebijaksanaan dalam pemberian balas jasa atau hukuman akan merangsang terciptanya kedisiplinan yang baik.

c. Dari hasil jawaban responden, indikator penekanan biaya mendapatkan skor terendah sebesar 3,45 namun sudah dalam kondisi yang baik pada variabel kinerja karyawan. Sebaiknya rencana anggaran pada setiap divisi yang lebih diperhatikan dalam setiap aktivitas perusahaan dengan biaya yang sudah dianggarkan tersebut merupakan sebagai acuan agar tidak melebihi dari yang sudah dianggarkan sehingga tidak terjadi pengeluaran yang berlebihan.

\section{DAFTAR PUSTAKA}

AA. Anwar Prabu Mangkunegara. (2013). Manajemen Sumber Daya Manusia Perusahaan. Bandung: Remaja Rosdakarya.

Afandi Pandi. 2018. Manajemen Sumberdaya Manusia Teori Konsep Dan Indikator. Pekanbaru: Zanafa Publishing

Ayol, Henry. (2010). Manajemen Public Relations. Jakarta: PT Elex Media.

Edison. (2016). Manajemen Sumber Daya Manusia, Bandung : Alfabeta

Edy Sutrisno.(2018) Manajemen Sumber Daya Manusia. Jakarta: Prenadamedia Group.

Eka, P. D. (2020). Analisis Pengaruh Keselamatan Kerja Dan Pelatihan Terhadap Kinerja Karyawan Pada PT Berca Schindler Lifts Project Alfa Tower Tangerang. JENIUS (Jurnal Ilmiah Manajemen Sumber Daya Manusia), 3(2), 198-207.

Emron Edison.(2016) Manajemen Sumber Daya Manusia,Bandung: Alfabeta

Fred Luthans.(2006), Perilaku Organisasi. Edisi Sepuluh, PT. Andi: Yogyakarta

G.R Terry dan Leslie W Rue. (2014). Dasar-Dasar Manajemen.Terjemah G.A Ticoalu. Jakarta: PT Bumi Aksara 
Ghozali, Imam. (2011). Aplikasi Analisis Multivariate Dengan Program SPSS. Semarang: Badan Penerbit Universitas Diponegoro.

Hartatik, Puji Indah. (2014). Buku Praktis Mengembangkan SDM. Jogjakarta: Suka Buku Hasibuan, Malayu S.P.(2018). Manajemen Sumber Daya Manusia. Edisi Revisi. Jakarta: PT Bumi Aksara

Kasmir. (2016). Manajemen Sumber Daya Manusia (Teori dan Praktik).Depok: PT Rajagrafindo Persadas

Muslimat, A., Muhsin, H., Wahid, H. A., Yulistiana, I., Sunarsi, D., Dewi, K., ... \& Ilham, D. (2021). Develop Technology Based Multimedia For Indonesian Teachers. Journal of Contemporary Issues in Business and Government, 27(1), 1871-1882.

Prasada, D., Sunarsi, D., \& Teriyan, A. (2020). Pengaruh Etos Kerja Dan Kompensasi Terhadap Komitmen Organisasi Pada DHL Logistic Di Jakarta. JENIUS (Jurnal Ilmiah Manajemen Sumber Daya Manusia), 4(1), 51-60.

Priansa, Donni Juni. (2018). Perencanaan \& Pengembangan SDM. Bandung: Alfabeta

Richard L Daft. (2010). Era Baru Manajemen. Jakarta: Salemba Empat.

Rivai, Veithzal dan Ella Sagala, (2013). Manajemen Sumber Daya Manusia untuk Perusahaan.Jakarta: Rajawali Pers

Sarinah dan Mardalena. (2017). Pengantar Manajemen. Yogyakarta: CV. Budi Utama.

Sarinah Sihombing, Simon Gultom, dan Sonya Sidjabat. (2015). Manajemen Sumber Daya Manusia Edisi Revisi. IN MEDIA

Sedarmayanti.(2017). Perencanaan dan Pengembangan SDM.Bandung: Refika Aditama.

Sudarso, A. P. (2020). Pengaruh Motivasi Dan Disiplin Kerja Terhadap Kinerja Pegawai Pada Kantor Kecamatan Pamulang Kota Tangerang Selatan. JENIUS (Jurnal Ilmiah Manajemen Sumber Daya Manusia), 3(2), 179-189.

Sugiyono. (2017). Metode Penelitian Kuantitatif, Kualitatif, dan R\&D. Cetakan ke 25. Bandung : Alfabeta, CV.

Suryani, N. L., Sularmi, L., Eka, P. D., Sunarsi, D., \& Maddinsyah, A. (2020). The Analysis of Career Development and Placement of Employee Performance in Pt. Global Means of Transindo in Jakarta. Solid State Technology, 63(6), 1382-1389.

Suwatno. (2012). Manajemen Sumber Daya Manusia di Organisasi Publik dan Bisnis. Jakarta: Erlangga 